\title{
The development and practice of socialization service in Chinese university library
}

\author{
Na Lin', a \\ ${ }^{1}$ Jilin Agricultural University, Changchun, Jilin province, China \\ a36670921@qq.com
}

Keywords: Colleges and Universities, Libraries, Social services, Practice and Development

\begin{abstract}
In this paper, with the introduction of the socialization of university library information service mode, points out the necessity and feasibility of the information service socialization of university library, and further discusses the restriction factors for developing the socialized service of university library, and try to give countermeasures, for our country university library socialization service mode innovation provides a new train of thought.
\end{abstract}

\section{Introduction}

The knowledge economy and the rapid development of network information technology has brought unprecedented opportunities and challenges to the development of the library. On the one hand, knowledge as a kind of important resources and factors of production, need to be better to organize and manage to achieve value-added; On the other hand the library how to use new technology to improve their service and competitiveness, is a new task faced by the library development.

At present, the university library to carry out the extent of the socialized service by local policy guidance, the school development, the needs of the development of local economy, culture, several factors of restriction and influence, openness is differ, the effect is different also. University library in the way of the socialized service has made a bold attempt to higher vocational library and public library from the aspects such as people, money, material for all-round closer integration, not only meet the information needs of the school teaching, scientific research, and fully opened to the public.

\section{University library socialization service mode}

In today's society is changing and developing of a learning society, people need to continue to learn and update knowledge. As people to the social development, community service and community construction consciousness gradually strengthened, the demand for books information is becoming more and more urgent [1]. Under this situation, to participate in the community education in colleges and universities, especially involved in university library, conform to The Times development and education, because the university library has rich resources and the advantage of information technology, and owns a professional talent team can provides the high-quality service for the reader, it can for the country save a lot of manpower and material resources, and can solve the urgent need in the community culture construction.

Each specific local universities both in education system, and will be in a certain community system, and the organic combination of various kinds of social organizations in the community, interdependence, mutual influence, mutual constraints, constitute the system of community [1]. But due to the limitation of social nature and understanding of community education, school and community contact did not form a benign two-way communication process, the community education is not able to play its proper functions, social transformation also failed to achieve the ideal effect.

\section{The socialized service of university library}

With the rapid development of computer and network technology and popularization, the information of the massive amounts of huge increase, the diversification of information carrier and 
virtualization, the accuracy and timeliness of information demand and the way of self-acquired knowledge, the library has been completely different from the previous sense has hidden useful library, the function of hidden has greatly decreases, and the knowledge of the network has been unable to use the space to measure, so the library must change its functions, explore its survival and development, to adapt to the demand of the times [2]. For university library, and its innovative expanding functions of education, the information quality education as the main function, establishing the image of their own knowledge.

Developing university library socialization service system. University library and the city library after integration, established a new management system and working mechanism. "A body, two pieces of brand" management model.

Promote the library service socialization is helpful to the benign development of the economic and social, activate the social cell, enhance people's sense of honor, social responsibility, effectively reduce the library fiscal expenditure, fixed to improve the service efficiency of funds. Library service socialization effectively circumvent the authority level, different social organizations to participate in social service at the same level, accept the service regulation [2]. This approach has many developed countries in the world are very mature, some countries such as Japan and the European Union public voluntary service is higher than that of services to the government, social organization form the whole country two big service principals. Development in our country, civil society organizations number on the rise, but the role and effect is not obvious, or completely according to administrative functions under another form of quangos. Such as the Red Cross, youth development foundation, charity federation, association for science and technology, writers association, society, etc. With a strong bureaucratic colour, its service all have strong habits of officialdom, the common understanding of civil society organizations exist error. Some leading policy on the groups hold a lack of understanding, thought rigid and stubborn attitude, it is difficult to form the administrative functions and social organization checks and balances the tacit understanding, each other tolerant service effect, prolonged standoff mistrust.

To strengthen the construction of marketization of library service system. Only a sound legal system can guarantee the standardization of the marketization process, to facilitate the government supervision and control. This would require the government to provide effective institutional guarantee, reduce the cost and risk factors in the process of marketization [3]. On the one hand, the government needs to set up perfect laws and regulations system, prevent the private sector to fraud and collusion, public or private. The democratic supervision system is not sound in China, has yet to establish open, fair and impartial tender and bidding system, there is no strict auditing system. In this case the marketization reform, hard to avoid appear "black-box", this would increase the cost and risk of library service, so you must publish relevant laws and regulations as soon as possible, such as the anti-monopoly law, and establish and improve the openness, fairness, justice, bidding, bidding system, ensure good reputation, quality excellent, price is low enterprise contract library services. On the other hand, the government should pass legislation, to create a fair development environment for socialization of library service.

Perfect the supervision system of library services. Library service marketization reform involves the use in the field of government administrative power in the market, the government in determining the service price, selection of service providers and regulatory rules have larger discretion. If there is no relevant supervision system of form a complete set, it is easy to corrupt, trade power, etc. Corruption scandals in library service marketization reform abroad, also strongly proves this point [3]. Therefore, the Chinese government in the implementation of the reform, it is important to pay special attention to the integrity system of related. Except for online office, perfecting the government affairs public, the government also need to standardize the corresponding operation process, maintain cohesion between each work link, to open complaint channels at the same time, give full play to the positive role of supervision by public opinion and the masses supervision. To enhance the quality of the library management. Government exercise of library management functions, ultimately to simplify a specific activity, the government management of ideological quality, professional quality directly affect the government's ability of library management. From the 
current actual situation in our country, cultivating a large number of library management personnel with high quality, is the effective regulation to the marketization of library service priority.

Seriously implement the system of library services. Library service career development is the responsibility of the government. Regardless of the socialist system, or the capitalist system, development of the library service should be the responsibility of the government [3]. Promote the reform of marketization of library services, what has changed is not the enterprise and the head of a local government or by the relationship between the leadership, but the introduction and practice in library service career market mechanism

Increase the intensity of open. The author found in thorough research in university library, university library and jiyuan city library belongs to a full range of resources integration. Although jiyuan city library was established early, but before the merger of collection resources is relatively small, and there are books is worn out, the problems such as nonstandard catalog. "Second house", university libraries play a staff with high quality, special features of the original resources construction norms to public library books cataloging, to establish a standardized management system, implement the full open, big circulation, the service mode of the service [2]. This mode, whether social readers or technical college teachers and students readers, all alike, any reader all can according to the requirements of the self, to borrow.

\section{The problems and coping strategies}

The balance of resources construction problems and deal with it. In the process of resources construction, how to balance the collection resources construction, do both balancing the needs of college education teaching of the literature information, and meet the social public to the latest literature resources. Half-and-half construction is definitely not a wise choice, but as long as we in the college library and public library administrative subordination relations with a little research, it's not hard to find a solution [4]. Colleges and universities generally founded by the government at the next higher level pay, serving local development; As one of the public cultural infrastructure, public library resources construction is also done by funding at the next higher level. Considering the institutions of higher learning education system in recent years to build and deepen the reform of talent cultivation mode, resource construction in university library, should be the priority to meet the needs of personnel training mode reform of colleges and universities, reasonable allocate resources, to meet the cultural needs of the public.

Different types of conflict between readers and deal with. In the process of the university library to carry out the socialized service, and the existence of inevitable social the public and the status of the college teachers and students compete for resources. This problem has always been, and still didn't get a reasonable solution [4]. A prominent problem reflects the social public school students readers often seat, especially encounter the holiday season and the college exam week approaches, crowded, social readers are hard to find seats in the library; While college students are often reflect, part of the social readers quality is low, and even affect students inside the library self-study, etc. Face this kind of problem, actually improve slightly on management. Management from two kinds of readers use the library to adjust the time and space, by readers for campus open self-study places, usually focus on the reader service for the school, on weekends and holidays will be service method such as the focus to the public readers can make effectively ease the contradiction between the different types of readers.

Librarians treatment problems and solutions. After the university library to carry out the socialized service, work longer, work add up to all of these is the problem to be reckoned with. Higher college library practice socialization management, since the opening mode to open 365 days all the year round, no day off, no holidays [4]. Since such, as compared to the faculty of other departments with college equal pay is different, even because of job performance difference treatment lower phenomenon. This problem is also hinder the socialized service process is one of the key factors of colleges and universities. Within the scope of the policy permits, to improve and enhance librarians pay a little bit, improve their professional identity and sense of honor, to the advancement of Chinese university library socialization service, is undoubtedly has a promoting effect. 
The introduction of talent and continuing education problems and deal with. Since practice socialization management service of university library, after nearly six years, without the introduction of a talent, re-education opportunities existing librarians outbound is extremely rare [3]. It did not work with treatment of the librarians of matching, human resources, lack of construction for a long time for librarians can't see the hope of rising personal space, prone to job burnout. To solve this problem, need to college leadership from the decision-making level to establish the corresponding talent training mechanism, and implement.

\section{The significance of the socialization of university library development}

Help ease China's current social books resources prominent social problem. In China's efforts to build a harmonious socialist society in the process of facing the biggest challenge lies in: the unbalanced development between regions and between urban and rural residents, the income gap is larger, resources and environment constraints, increase, internal and external imbalances, investment problem such as the consumption structure is not reasonable [5]. These issues with China currently exist two more closely related to prominent contradictions: one is the residents of the growing demand of public service and overall supply of public service, the contradiction between the low quality; Second, the market economic system gradually establish and improve the new requirements for the functions of the government and the contradiction between the slow change of government function. Public service is the basis of maintaining social basic fair, usually playing the social contradictions "buffer" function. , therefore, to strengthen the government's public service function, accelerate the improvement of Chinese public service conditions, conducive to ease China faces all sorts of prominent contradictions in current economic and social, promoting the construction of harmonious society smoothly.

Mechanism is conducive to improve the supply of the public library service system. Current in Chinese government public service responsibilities, not form a sustainable financial support system, no division of labor and establish a standardized government accountability, not form a fair allocation of resources between regions and between urban and rural system, which seriously affected the public books provide the quantity and quality of service, and restricts the efficiency of the basic public library services [5]. To strengthen the government public service performance management, strengthen the responsibility of the governments at all levels and government departments, promote the formation of indirect competition mechanism between the government, to perfect China's public library service supply all kinds of systems and mechanisms, gradually guide the governments at all levels set by the public service as the center of the government function view and performance view.

To improve public resources allocation efficiency as a whole. The government function of resource allocation not only failed to weaken but also in continuously strengthen. Although China's fiscal spending as a share of GDP in 2005 was only 18.5\%, but from the government's actual command the resources and the function range, China belongs to "big government" [2]. In the face of global government scale expanding by the increasing trend, the government control over resources, improving the government management, improve the efficiency of the government, especially to strengthen its core responsibilities - performance management of public service, is conducive to improve the efficiency of the whole social resource allocation and improve the national welfare as a whole.

Benefit to the public to participate in the management and supervision of the public service. As the informationization level and the continuous improvement of people's living standard, more and more public demand for public services, more and more high quality requirements, the differences between the national and local public service is becoming more and more sensitive, is no longer merely content with the know how much the government spent on public services, more concerned about the spending which results have been achieved [5]. What life brings to the public job real improvement. From meet the demand of information level, the public service of government performance evaluation, and form a regular public report system, not only for the government to further improve China's public service provide decision-making reference, and can meet the information needs of the public, improve their ability to participate in government management and 
supervision, will be conducive to the decision-making scientific and democratic, is helpful to improve the government's credibility in the public mind.

\section{Summary}

Combined with the municipal public library and university library to carry out the socialized service pattern of information resources in the process of Chinese university library socialization service is a bold attempt and practice, to a large extent is a very successful operation pattern. The formation and development of this model has a very distinctive social and geographical features, the Midwest provinces and autonomous regions in China, colleges and universities library resources construction and the local public library resources construction is the lack of cases, it has certain feasibility and operability. Through the government decision-making, the organic integration, focus on the limited resources, the complementary advantages of resources, equipment, implementation and sharing of document resources, make the university library really go into the public life, provide intellectual support for the development of regional economy, culture and information security.

\section{References}

[1] X.M. Wei, The joining together of two hall - mode of university library socialization service inquiry in university library--for example intelligence development of science and technology and economy, Information Development and Economy, 2013, vol.2, pp.84-86.

[2] H.P. Jin, The university library and public library innovative service mode combined. Journal of Jiyuan vocational and technical college, 2009, vol.9, pp.122-124

[3] X.Tang, The university library socialization service. Work of university library, 2005, vol.6, pp. 59-60.

[4] J. Yao, More on local socialization of university library information service work in the new period of analysis, Science and technology intelligence development and economy, 2006, vol.6, pp. 13-14.

[5] H.T Ma, The information service of university library under the knowledge economy, Journal of Shandong agricultural management cadre institute, 2005, pp. 21-26. 